\title{
The Ghrelin Receptor (GHSR) Gene Polymorphism in Indonesian Local Chicken and Crossbreed is Associated with Carcass Traits
}

\author{
Isyana Khaerunnisa ${ }^{1,2}$, Jakaria ${ }^{2}$, Irma Isnafia Arief², Cahyo Budiman'², Cece Sumantri ${ }^{2,3^{*}}$ \\ ${ }^{1}$ Graduate School, Bogor Agricultural University (IPB), Animal Production and Technology Study Program. \\ Jl. Agatis, Darmaga Campus, Bogor 16680, Indonesia. \\ 2Department of Animal Production and Technology, Faculty of Animal Science, Bogor Agricultural University (IPB). \\ Jl. Agatis, Darmaga Campus, Bogor 16680, Indonesia. \\ ${ }^{3}$ Research Center for Bioresources and Biotechnology, Bogor Agricultural University (IPB). \\ Jl. Kamper, Darmaga Campus, Bogor 16680, Indonesia. \\ *Corresponding author email: isyanakhaerunnisa@gmail.com
}

\begin{abstract}
Ghrelin receptor (GHSR) gene is candidate gene for growth performance in chicken by modulating growth hormone release from the pituitary by binding to its ligand of ghrelin. Ghrelin, or growth hormone secretagogue (GHS), is well known as feed intake and energy homeostasis regulator in mammals and birds. The objectives of this study were to identify the polymorphism of the T1857C GHSR locus in Indonesian local chicken and to evaluate its effects on carcass traits. The gene polymorphism was identified using polymerase chain reaction-restriction fragment length polymorphism (PCR-RFLP) using Hin6I restriction enzyme. Effect of genotype on carcass traits was analyzed using SAS General Linear Model (GLM) procedure. The genotyping was performed on 343 individuals including Merawang, Pelung, Sentul, Kampung, broiler (strain Cobb, parent stock), F1 Kampung $\mathrm{x}$ broiler cross, and F2 Kampung $\mathrm{x}$ broiler cross. All individuals were successfully amplified and were resulted a $470 \mathrm{bp}$ PCR product. This locus was polymorphic with two alleles ( $T$ and $C$ ) and three genotypes (TT, CT, and CC). The T allele and TT genotype were predominant in all populations. Individuals with CT genotype were significantly had higher live weight at 26 weeks, carcass weight, commercial cuts weights, and muscles weights than TT genotype in F2 Kampung $x$ broiler cross population. Association of the T1857C GHSR locus polymorphism with chicken carcass traits has been described in Indonesian chicken, providing evidence that GHSR might be an important candidate gene for chicken carcass traits.
\end{abstract}

Key words: Indonesian local chicken, crossbreed, GHSR gene, carcass traits

Abstrak. Gen reseptor ghrelin merupakan gen kandidat penciri sifat pertumbuhan pada ayam, yang bekerja melalui mekanisme modulasi pelepasan hormon pertumbuhan dari pituitari dengan cara berikatan dengan ghrelin. Ghrelin, atau growth hormone secretagogue (GHS), dikenal sebagai pengatur konsumsi pakan dan keseimbangan energi pada mamalia dan unggas. Tujuan penelitian ini adalah mengidentifikasi polimorfisme lokus GHSR T1857C pada populasi ayam lokal Indonesia dan mengavaluasi pengaruh polimorfisme tersebut dengan sifat karkas. Analisis polimorfisme dilakukan menggunakan teknik PCR-RFLP berdasarkan enzim pemotong Hin6l. Pengaruh genotipe terhadap sifat karkas dianalisis menggunakan prosedur GLM dengan aplikasi SAS. Analisis polimorfisme dilakukan pada 343 ekor ayam yang terdiri dari populasi ayam Merawang, Pelung, Sentul, Kampung, broiler (strain Cobb, parent stock), silangan F1 Kampung x broiler, dan silangan F2 Kampung $x$ broiler. Amplifikasi lokus GHSR menghasilkan produk PCR sepanjang 470 pb. Lokus T1857C GHSR ini bersifat polimorfik dengan dua alel ( $T$ dan $C$ ) dan tiga genotipe (TT, $C T$, dan $C C$ ). Alel $T$ dan genotipe TT ditemukan dengan frekuensi tertinggi di seluruh populasi. Individu dengan genotipe CT memiliki bobot badan (26 minggu), bobot karkas, bobot potongan komersial, dan bobot otot yang lebih tinggi dari pada genotipe $T T$ pada ayam silangan F2 Kampung x broiler. Asosiasi polimorfisme lokus GHSR T1857C dengan sifat karkas ini membuktikan bahwa GHSR merupakan gen kandidat penting untuk seleksi sifat karkas pada ayam.

Kata kunci: ayam lokal, silangan, gen GHSR, sifat karkas

\section{Introduction}

Ghrelin receptor, a member of G-proteincoupled receptor family, is a modulator of growth hormone release from the pituitary by binding to its endogenous ligand, ghrelin (Kaiya et al. 2013, Yin et al. 2014). Ghrelin gene is well known as feed intake and energy homeostasis regulator in mammals and birds (Lengyel 2005, Zendehdel and Hassanpour 2014) and stimulates appetite (Honda et al. 2017). The peptide hormone ghrelin contains a unique 0 - 
acyl linked octanoyl group on Ser3 modification and this is essential for the binding of ghrelin to the receptor (Großauer et al. 2010).

Chicken GHSR gene, firstly discovered by Tanaka et al. (2003), known as Growth Hormone Segretagogue Receptor (GHSR). This gene is located in chromosome 9 , consists of $4.1 \mathrm{~kb}$ with two exons separated by an intron and produces 347 amino acids (Nie et al. 2005, Tanaka et al. 2003). Nie et al. (2005) reported 37 SNPs occurred in the cGHSR gene, including nine synonymous SNPs, two nonsynonymous SNPs, 25 SNPs in intron, and one SNP in 3'UTR. In non-mammals, ghrelin receptors are more complex and diverse than in mammals (Kaiya et al. 2014). Different with mammals which only have 2 variants of GHSR gene (GHS-R1a and GHS-R1b), Kaiya et al. (2013) summarized that birds have one regular splicing (GHS-R1a) and five alternative splicing variants (GHS-R1b, GHSR1aV, GHS-R1bV, GHS-Rtv, and GHS-Rtv-like) of the GHSR gene. This GHS-R1a, which is considered as active form of GHSR, was found to mediate various physiological functions of ghrelin (Kaiya et al. 2013, Yin et al. 2014).

In human, GHSR gene polymorphism was reported to have an association with eating behavior (Gueorguiev et al. 2009), obesity and glucose metabolism (Mager et al. 2008), and colorectal cancer risk (Campa et al. 2010). Studies of GHSR gene have been reported in other animals, such as cattle (Komatsu et al. 2015), duck (Nie et al. 2009), quail (Kitazawa et al. 2009), and goldfish (Sánchez-Bretaño et al, 2015). Some GHSR gene polymorphisms in chicken were reported have strong relations with growth traits (Fang et al. 2010), fat and muscle fiber (Lei et al. 2007), and body composition (Niarami et al. 2014). Fang et al. (2010) reported a polymorphism located in intron 1 (T1857C) related to growth traits in chicken. To our knowledge, no studies have examined the characteristics of this GHSR locus in Indonesian chickens.
Kampung chicken is Indonesian indigenous chicken that is traditionally reared in rural area. This breed is classified as slow growing chicken. The crossing with fast growing chicken, such as commercial broiler chicken, could improve growth and carcass traits of Kampung chicken. Sheng et al. (2013) suggested that intercross with commercial broiler chicken could improve genetic potential of Huyang Beard chicken, a Chinese slow growing chicken. Therefore, this present study was aimed to identify genetic polymorphism of the T1857C GHSR locus in Indonesian chicken and the crossbreed, and investigate the effect on the carcass traits.

\section{Materials and Methods}

\section{Ethics Statement}

All experimental protocols described in this study were approved by the Animal Care and Use Committee (ACUC), Bogor Agricultural University (Approval ID: 22-2016 IPB).

\section{Experimental Birds and Data Collection}

The present study was conducted on 343 birds of seven chicken populations, namely broiler strain Cobb, parent stock (37), Kampung (49), Merawang (57), Pelung (23), Sentul (36), F1 Kampung $\mathrm{x}$ broiler cross (42), and F2 Kampung $\mathrm{x}$ broiler cross (99). The Kampung, Merawang, Pelung, and Sentul are Indonesian local chickens. All birds were maintained at the Department of Animal Production and Technology, Faculty of Animal Science, Bogor Agricultural University, Indonesia. All birds were fed and raised under the same environmental conditions. Blood sample from each bird was obtained from the wing vein and was collected into tube containing EDTA as anticoagulant. The total DNA was isolated from blood according to Sambrook and Russel (2001) with minor modification as briefly described by Khaerunnisa et al. (2016).

Carcass traits of 44 birds ( 22 male and 22 female) of the 26-weeks-old F2 Kampung $x$ 
broiler (strain Cobb, parent stock) cross were recorded for association study. The live weights, carcass weights and percentages, and commercial cuts weights and percentages were recorded for carcass components data. The physicochemical characteristics including $\mathrm{pH}$, free water ( $m g \mathrm{H}_{2} \mathrm{O}$ and $\% \mathrm{mg} \mathrm{H}_{2} \mathrm{O}$, using filter paper press), meat tenderness (Warner Bratzler Shear Force), and cooking loss were measured from breast muscle after frozen storage $\left(-20^{\circ} \mathrm{C}\right)$ for three months.

\section{Amplification and Genotyping}

The GHSRf (5'-CCC ACA AAG TTA GCT GCA GAC- $3^{\prime}$ ) and GHSRr (5'-ATC CAT GGG AGC TCA TGC TG-3') primers were designed to determine the polymorphism of the T1857C GHSR locus (Figure 1). The T1857C GHSR locus was previously reported by Fang et al. (2010). These primers generated $471 \mathrm{bp}$ DNA fragments located in intron 1 (Figure 1). All primers were designed using Primer Designing Tool (http:// www.ncbi.nlm.nih.gov/tools/primer-blast/) according to National Centre of Biotechnology
Amplification was performed in $25 \mu$ total volume containing $50 \mathrm{ng} / \mu \mathrm{l}$ DNA template, 0.5 pmol primers (Integrated DNA Technology, Singapore, Singapore), 0.5 unit GoTaq Green Master Mix (Promega, Madison, USA), and water. This mixture was incubated in a thermocycler machine (GeneAmp ${ }^{\circledR}$ PCR System 9700, Applied Biosystems, Foster City, USA). The amplification was performed in 30 cycles of denaturation at $95^{\circ} \mathrm{C}$ for $10 \mathrm{sec}$, annealing at $60^{\circ} \mathrm{C}$ for $20 \mathrm{sec}$, and elongation at $72^{\circ} \mathrm{C}$ for 30 sec.

The Restriction Fragment Length Polymorphism (RFLP) technique was performed to determine the T1857C SNP. The Hin6l (Thermo Fisher Scientific, EU, Lithuania) was used as restriction enzyme for this locus. The PCR products were loaded into $2 \%$ agarose gel containing FluoroSafe DNA Staining (1st Base, Singapore) for bands visualization under the UV Transilluminator (Alpha Imager, Alpha Innotech, Santa Clara, USA). Three PCR products from each genotype were sequenced using an $\mathrm{ABI}$ PRISM3730 sequencer (1st Base, Singapore) to

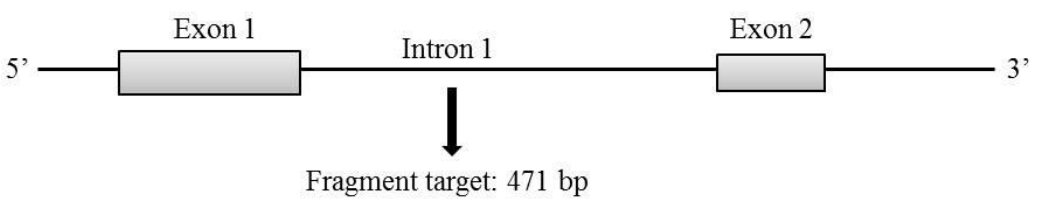

GHSRf

1471 ATCTGATTTT CAAACTAACC TCTTCTAAAC CCACAAAGTT AGCTGCAGAC TAAGCAAGCA GGGTGTGATG 1541 TGCACTGACT TTCAAATGAA AAgGCATtTT TAgCAAAtTg GGGTAATTTA GCCAgCGTGA CTGTTTAAgA

1611 TCATGGAAAg TGATCTTATT CTCTGCATTA GCAAAGCATC AGCCTTTGCT GAACAGTGAC CATTTTGTCT 1681 CCCTCAGGgt CTATAATCCC CTAAATTCCC ACCGACTTCA GGGTAACAGg ATGGAGACGA CAGACGCTGT 1751 CAGTCCTGAC AGTGTATTTA CACAGCCGCA TGGTTTAAAC AACAGACACT GCTGGCACAC AGAAGAGCAC 1821 GTTCAGCACA GGGATGCTGg CAGCTCCTGA CAAGCGT GTg CCAGGAGCTg GCTGCACAGg ACCCAAAGTT 1891 GCTGCACAGA TCCATGCCTG GTCACTGAGC ACCGCTGCAT GCTTTTGCAC TGACAGATCC CAGCATGAGC

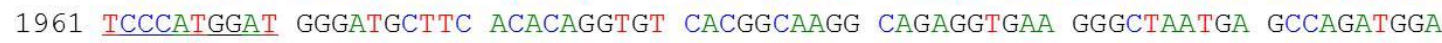
GHSR

C allele (restricted) : $5^{\prime}---$ CAAGICGCGTG----3'
T allele (unrestricted): $5^{\prime}---$ CAAGCGTGTG----3'

Information (Accession number: AB095994.1). verify the mutation.

Figure 1. Fragment target GHSR | Hin6I locus (intron 1), and resulted the $T$ and $C$ allele (position T1857C). Underline shows forward and reverse primer annealing position; box shows Hin6l restriction site (GenBank accession number: AB095994.1). 


\section{Statistical Analysis}

Genetic polymorphism information, including genotype frequency, allele frequency, heterozygosity, and the Hardy-Weinberg Equilibrium, were analyzed according to Nei and Kumar (2000). SAS GLM procedure and Duncan multiple range test were performed for association analysis between the T1857C genotype with chicken carcass traits (SAS Institute 2008). The genetic effects were analyzed using this following model:

$$
Y_{\mathrm{ijk}}=\mu+S_{i}+G_{j}+\varepsilon_{i j k}
$$

Where $y_{i j k}$ is the observed phenotypic trait (carcass traits) for $k_{\text {th }}$ individual with $i_{\text {th }}$ sex and $\mathrm{j}_{\text {th }}$ genotype, $\mu$ is the overall mean, $S_{i}$ is the genetic effect of $i_{\text {th }}$ sex, $G_{j}$ is the genetic effect of $j_{\text {th }}$ genotype, and $\varepsilon_{\mathrm{ijk}}$ is the normally distributed residual error.

\section{Results and Discussion}

\section{Polymorphism of the T1857C GHSR Locus}

The T1857C GHSR locus, which is located in intron 1 , was successfully amplified and showed a 470 bp fragment (Figure 2, 3). This result was different with the reference sequence (GenBank accession number: AB095994.1) due to one bp indel observed in position $134 \mathrm{bp}$ (Figure 3). Genotyping analysis was performed using Hin6l restriction enzyme. This enzyme recognized and digested at GCG $\mid \mathrm{C}$ sites, generated two alleles ( $C$ and $T$ ) and three genotypes (CC, TT, and $\mathrm{CT}$ ). The $\mathrm{T}$ allele was indicated by a 470 bp band (unrestricted), while

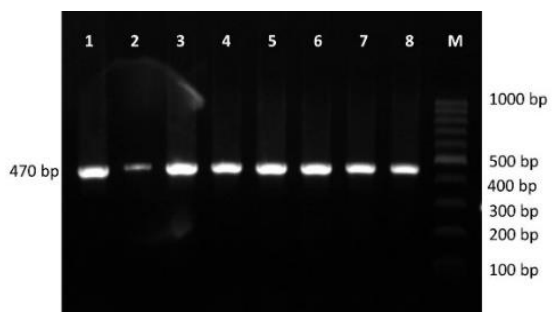

a) the $C$ allele was indicated by 354 and 116 bp (restricted, Figure 2). According to the sequencing result, the T1857C GHSR mutation was occurred from nucleotide $T$ to $C$ in position 357 bp (Figure 3).

The TT genotype was found to be the highest in all chicken populations, while the CC genotype was found only in Kampung, Merawang, and Pelung populations in very low frequencies $(0.020,0.035$, and 0.043 , respectively). The frequency of the $\mathrm{C}$ allele in all studied chicken populations was low (0.136), yet in the Pelung population this rare gene variant was the most frequent (0.283). Kampung chicken showed the highest frequency of the TT genotype (0.918) and the T allele (0.949). This frequency was lower in the Kampung $\mathrm{x}$ broiler chicken cross ( $\mathrm{F} 1$ and $\mathrm{F} 2$ ) due to the introduction of more $\mathrm{C}$ allele from broiler chicken. However, no CC genotype was found in these two populations. Similar result was reported by Feng et al. (2010) in F2 chickens designed by crossing White Recessive Rock and Xinghua chicken. The TT genotype was higher than the $\mathrm{CT}$ and $\mathrm{CC}$ with frequency $0.673,0.316$, and 0.011, respectively (Feng et al. 2010). All chicken populations in this study were classified as polymorphic, as $\mathrm{Nei}$ and Kumar (2000) mentioned that genetic polymorphism is defined as the existence of two or more alleles with usually more than one percent relative frequencies in a population. Data related to allele and genotype frequencies is presented in Table 1.

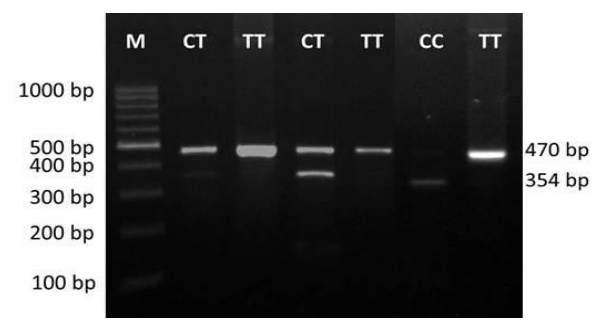

b)

Figure 2. Amplification and polymorphism detection of the T1857C GHSR locus. a) Amplification of GHSR gene partial intron 1 in $1.5 \%$ agarose gel. M=DNA ladder; 1-8= sample. b) Genotyping of the T1857C GHSR locus in $2 \%$ agarose gel. M=DNA ladder; CC, TT, CT= genotype. 


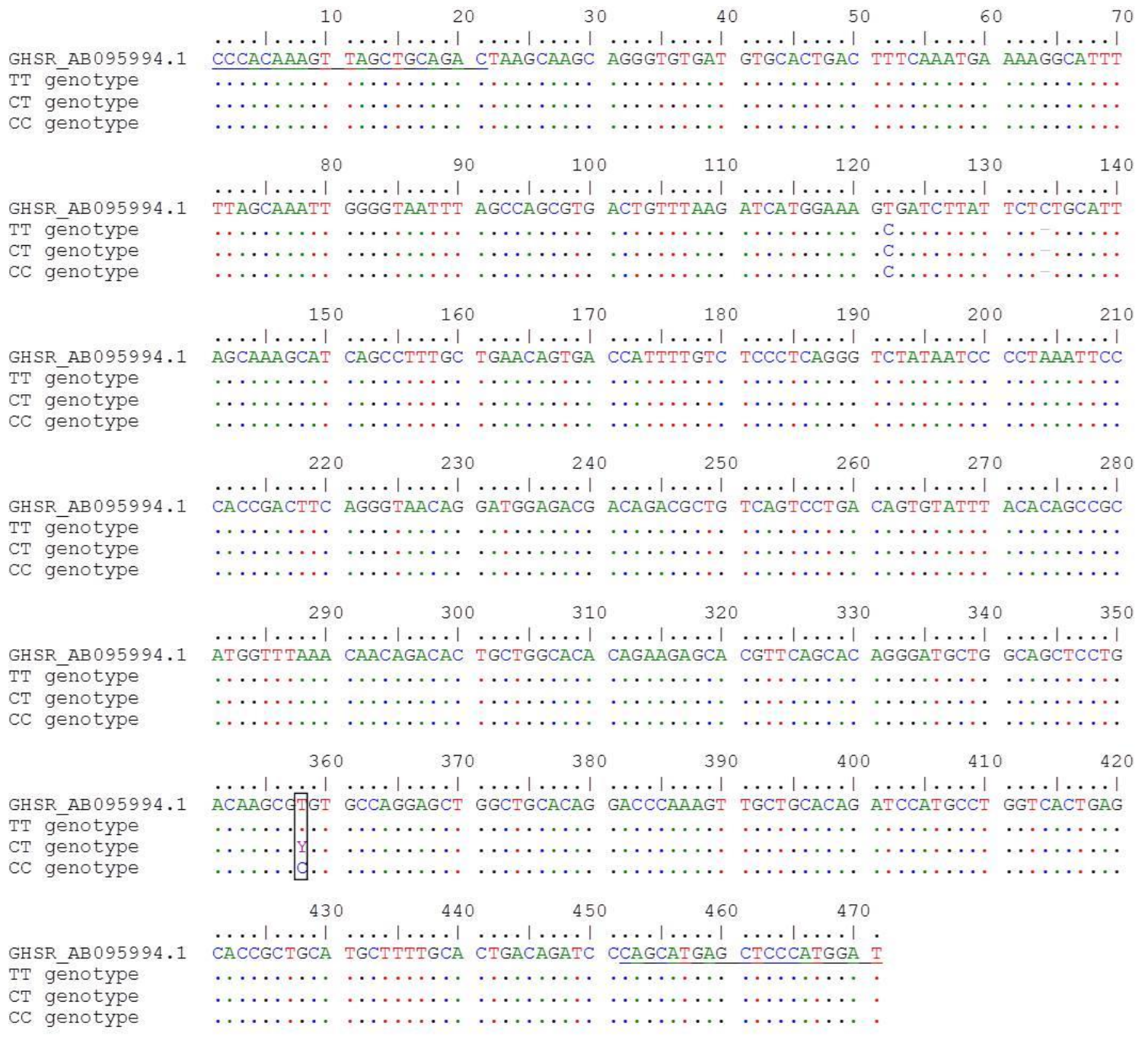

Figure 3. The chicken GHSR gene partial intron 1 nucleotide sequence. Underline shows GHSRf and GHSRr primer annealing positions; box shows T1857C SNP target; Y shows IUPAC code for nucleotide C or T (GenBank accession number: AB095994.1).

The observed heterozygosity (Ho) value was higher than the expected heterozygosity $(\mathrm{He})$ in all chicken populations/breeds, exception in the Kampung population (Table 1). This indicated the occurrence of inbreeding due to an intensive selection of the T1857C GHSR locus in the Kampung population (Allendorf et al. 2013). In the purpose of improving the meat productivity of Kampung chicken, a crossbreeding with meat-type chicken was designed in this study. This crossbreeding changed the heterozygosity of Kampung population (0.097) into 0.228 and 0.205, respectively for $F 1$ and $F 2$ chicken cross populations. This result of crossbreeding, or outbreeding, was an increase in heterozygosity and decrease in homozygosity (Bourdon 2000). The chi-square value shows that all chicken populations/breeds were in Hardy-Weinberg equilibrium, exceptions in Kampung population. This result showed that the allele and genotype frequencies in Kampung population were not constant from generation to generation (Allendorf et al. 2013). Nei and Kumar (2000) mentioned that the occurrence of inbreeding, assortative mating, natural selection, or population subdivision may disturb the HardyWeinberg equilibrium. The heterozygosity and chi-square value of this study are shown in Table 1. 
Table 1. Polymorphism of theT1857C GHSR locus

\begin{tabular}{|c|c|c|c|c|c|c|c|c|c|}
\hline \multirow{2}{*}{ Chicken Population/ Breed } & \multirow{2}{*}{$\mathrm{N}$} & \multicolumn{3}{|c|}{ Genotype Frequency } & \multicolumn{2}{|c|}{ Allele Frequency } & \multirow{2}{*}{ Ho } & \multirow{2}{*}{$\mathrm{He}$} & \multirow{2}{*}{$\chi^{2}$} \\
\hline & & TT & $\mathrm{CT}$ & $\mathrm{CC}$ & $\mathrm{T}$ & $\mathrm{C}$ & & & \\
\hline Broiler (strain Cobb, parent stock) & 37 & 0.676 & 0.324 & 0.000 & 0.838 & 0.162 & 0.324 & 0.272 & 1.386 \\
\hline Kampung & 49 & 0.918 & 0.061 & 0.020 & 0.949 & 0.051 & 0.061 & 0.097 & $6.626 *$ \\
\hline Merawang & 57 & 0.596 & 0.368 & 0.035 & 0.781 & 0.219 & 0.368 & 0.342 & 0.329 \\
\hline Pelung & 23 & 0.478 & 0.478 & 0.043 & 0.717 & 0.283 & 0.478 & 0.405 & 0.741 \\
\hline Sentul & 36 & 0.889 & 0.111 & 0.000 & 0.944 & 0.056 & 0.111 & 0.105 & 0.125 \\
\hline F1 Kampung $\mathrm{x}$ broiler & 42 & 0.738 & 0.262 & 0.000 & 0.869 & 0.131 & 0.262 & 0.228 & 0.954 \\
\hline F2 Kampung $\mathrm{x}$ broiler & 99 & 0.768 & 0.232 & 0.000 & 0.884 & 0.116 & 0.232 & 0.205 & 1.710 \\
\hline Total & 343 & 0.741 & 0.248 & 0.012 & 0.864 & 0.136 & 0.248 & 0.234 & 1.127 \\
\hline
\end{tabular}

Exploration of the GHSR gene polymorphisms in chicken has been reported in several studies. Nie et al. (2005) discovered 37 SNPs within 3628 bp of chicken GHSR gene in Leghorn, White Recessive Rock, Taihe Silkies, and Xinghua chickens. In the same chicken populations, Nie et al. (2009) found eight SNPs located in 5 'flanking region. Five SNPs have been reported by Lei et al. (2007) including one 6-bp insertion-deletion in F2 full sib White Recessive Rock $x$ Xinghua chicken population. This 6-bp insertion-deletion was also reported by Kaczor et al. (2017) in Hubbard Flex and Ross 308 broiler chickens. Niarami et al. (2014) reported a C3286>T synonymous mutation located in exon 2 in Iranian commercial lines.

\section{Effects of the T1857C Polymorphism on Carcass Traits}

In this study, the T1857C polymorphism was associated with the carcass component of F2 Kampung $\mathrm{x}$ broiler cross, but not with the physicochemical characteristics of Pectoralis major meat (Table 2). Carcass components influenced by this polymorphism were live weight, carcass weight, breast weight, thighs weight, drum sticks weight, wings weight, breast muscle weight, thighs muscle weight, and drum sticks muscle weight. Individuals with the $\mathrm{CT}$ genotype had higher value than the $\mathrm{TT}$ genotype among traits $(p<0.05)$. However, percentages of each carcass components were not affected by the T1857C polymorphism. This suggested that even though the CT genotype produced higher carcass components, it yielded proportional body composition and did not influence the meat quality.

This result was on the contrary to Fang et al. (2010). Fang et al. (2010) reported that the CT and TT genotypes had no difference in growth traits of F2 White Recessive Rock and Xinghua chicken cross. Higher body weight at 28 and 90 days of age, dressed weight, eviscerated weight with giblet, eviscerated weight, breast muscle weight, and leg muscle weight were found in the CC genotype compared to the CT and TT genotypes (Fang et al. 2010). Differences in the use of chicken breeds, slaughter age, and the environments are expected to lead different result between both studies. Moreover, the limited number of individuals in this present study yielded only the TT and the CT genotypes. This is also presumed to obtain different association result, since no CC genotype was found in the present study.

Association with meat physicochemical characteristics had been reported in the g.3051C>T and 6-bp ins/del GGTCAA loci of GHSR gene (Kaczor et al. 2017). The fastest growing chicken (with $\mathrm{CT} / \mathrm{Ins}$ Del diplotype) demonstrated higher $\mathrm{pH}_{24 \mathrm{~h}}$ value, darker meat, lowest thawing lost, and highest fiber diameter (Kaczor et al. 2017) than the slowest growing chicken. In the previous study, we emphasized different chicken growth and carcass components value with no difference in meat physicochemical quality. 
Table 2. The association of the T1857C GHSR polymorphisms with carcass traits in F2 Kampung $\mathrm{x}$ broiler chicken cross

\begin{tabular}{|c|c|c|c|c|c|}
\hline \multirow{2}{*}{ Trait } & \multicolumn{5}{|c|}{ Genotype } \\
\hline & \multicolumn{2}{|c|}{ CT $(n=7)$} & \multicolumn{3}{|c|}{$T T(n=37)$} \\
\hline \multicolumn{6}{|c|}{ Carcass components } \\
\hline LW (g) & 2757.57 & $\pm 208.94^{a}$ & 2097.20 & \pm & $497.34^{b}$ \\
\hline CW (g) & 1864.57 & $\pm 257.84^{\mathrm{a}}$ & 1367.22 & \pm & $325.88^{b}$ \\
\hline BW (g) & 468.57 & $99.83^{a}$ & 358.14 & \pm & $99.40^{\mathrm{b}}$ \\
\hline TW (g) & 345.14 & $41.91^{\mathrm{a}}$ & 253.46 & \pm & $71.77^{\mathrm{b}}$ \\
\hline $\mathrm{DW}(\mathrm{g})$ & 324.29 & $38.08^{a}$ & 246.97 & \pm & $72.50^{\mathrm{b}}$ \\
\hline WW (g) & 262.00 & $39.32^{\mathrm{a}}$ & 191.78 & \pm & $41.52^{b}$ \\
\hline BMW (g) & 346.00 & $95.61^{\mathrm{a}}$ & 251.86 & \pm & $74.98^{b}$ \\
\hline TMW (g) & 236.43 & $55.22^{\mathrm{a}}$ & 184.32 & \pm & $56.31^{b}$ \\
\hline DMW (g) & 214.71 & $40.58^{a}$ & 157.59 & \pm & $47.86^{b}$ \\
\hline $\mathrm{CP}(\%)$ & 67.53 & 6.90 & 65.31 & \pm & 5.22 \\
\hline $\mathrm{BP}(\%)$ & 24.93 & 2.37 & 26.27 & \pm & 4.03 \\
\hline TP (\%) & 18.60 & 1.44 & 18.46 & \pm & 2.14 \\
\hline DP (\%) & 17.52 & 1.92 & 17.99 & \pm & 2.48 \\
\hline WP (\%) & 14.04 & 0.45 & 14.21 & \pm & 1.67 \\
\hline BMP (\%) & 18.28 & 2.76 & 18.46 & \pm & 3.35 \\
\hline TMP (\%) & 12.81 & 2.86 & 13.40 & \pm & 2.01 \\
\hline DMP (\%) & 11.54 & $\pm \quad 1.65$ & 11.46 & \pm & 1.66 \\
\hline \multicolumn{6}{|c|}{ Physicochemical characteristics } \\
\hline $\mathrm{pH}$ & 5.57 & $\pm \quad 0.15$ & 5.56 & \pm & 0.28 \\
\hline $\mathrm{FW}\left(\mathrm{mg} \mathrm{H}_{2} \mathrm{O}\right)$ & 72.09 & 15.49 & 79.86 & \pm & 17.67 \\
\hline $\mathrm{FW}\left(\% \mathrm{mg} \mathrm{H}_{2} \mathrm{O}\right)$ & 24.03 & 5.16 & 26.69 & \pm & 5.88 \\
\hline $\operatorname{TND}\left(\mathrm{kg} / \mathrm{cm}^{2}\right)$ & 2.53 & 1.05 & 2.20 & + & 0.95 \\
\hline$C L(\%)$ & 42.61 & 3.95 & 41.51 & \pm & 6.46 \\
\hline
\end{tabular}

Note: $\mathrm{LW}=$ Live Weight; $\mathrm{CW}=$ Carcass Weight; $\mathrm{BW}=$ Breast Weight; $\mathrm{TW}=$ Thighs Weight; $\mathrm{DW}=$ Drum Sticks Weight; $W W=$ Wings Weight; $B M W=B r e a s t$ Muscle Weight; $T M W=$ Thighs Muscle Weight; $D M W=D r u m$ Sticks Muscle Weight; $C P=C a r c a s s$

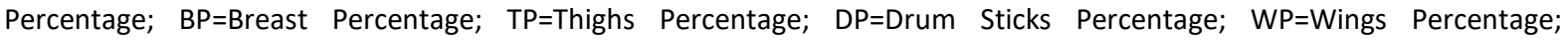
$\mathrm{BMP}=$ Breast Muscle Percentage; TMP=Thighs Muscle Percentage; DMP=Drum Sticks Muscle Percentage; FW=Free Water; TND=Tenderness; $C L=$ Cooking Loss; $n=$ number of sample; different superscript indicates significantly difference at the $\mathrm{P}<0.05$ levels for chickens with different genotypes of a given locus.

The physicochemical characteristics of chicken breast meat in this study were in agreement with various studies, exception the cooking loss. The $\mathrm{pH}$ value in this study was in accordance with 6 weeks of broiler breast meat ie 5.65-5.78 (Swattitanun and Wattanachant 2014) and 24 weeks of Kampung chicken ie 5.48-6.28 (Winarso 2003). The percentage of free water of this study was similar to 24 weeks of Kampung chicken, which is in the range 18.0329.56 (Winarso 2003). The meat tenderness of study in accordance with the tenderness of local Thai chicken breast meat is 1.80-2.70 $\mathrm{kg} / \mathrm{cm}^{2}$ (Wattanachant 2008). The value of cooking loss in this study was higher than other studies such as reported in Thai local chicken ie 18.99-24.04\% (Wattanachant 2008) and broiler chicken ie $25.08-31.40 \%$ (Salakova et al. 2009). It is expected that this high percentage of cooking loss in this study is caused by the storage period as reported by Jaelani et al. (2014) in broiler chicken breast meat. Study conducted by Jaelani et al. (2014) concluded that the longer period of frozen storage could increase the cooking loss of the broiler chicken breast meat.

Ghrelin regulates the proliferation and differentiation through MAP kinase (MAPK) signaling (Yin et al. 2014, Rak-Mardyla 2013). Activation of GHS-R1a stimulates this ghrelin regulation (Kaiya et al. 2013). As the active form of GHSR, the GHS-R1a stimulates growth hormone release, food intake, and neutral activation through $\mathrm{PLC} / \mathrm{IP}_{3}$ signaling and 
subsequent intracellular calcium mobilization in the pituitary cells (Yin et al. 2014). Moreover, in the pituitary cells, GHS-R1a interacts with the GHRH receptor to enhance GHRH-induced cAMP signaling and its subsequent growth hormone release (Yin et al. 2014). The expression of GHS-R1a is predominant in the caudal lobe of chicken pituitary, and this is parallel with the expression of pituitary $\mathrm{GH}$ and proventriculus ghrelin mRNA (Yamamoto et al. 2008). The expression of GHS-R1a is regulated by transcriptional factors and hormones. Yin et al. (2014) explained that the Pit-1 is considered as an important transcriptional factor in the regulation of GHS-R1a expression. Further, both $\beta$-estradiol and triiodothyronine increase levels of GHS-R1a mRNA in cultured rat pituitary cells. In contrast, level of GHS-R1a mRNA is suppressed by hydrocortisone by inhibiting GHS-R1a gene promoter activity (Yin et al. 2014).

This present study used local chicken breeds crossed with commercial broiler chicken (strain cobb, parent stock) that has been intensively selected. This crossing the local chicken with broiler is aimed to increase the genetic potential of local chicken (Sheng et al. 2013). Besides crossing with the meat-type chicken, improving performance of local chicken can be done by selection (Padhi 2016). The association of the GHSR gene polymorphism with carcass characteristics has been described in Indonesian chickens crossbreed for the first time. In this study, we recommend the T1857C GHSR locus can be used as a genetic marker for chicken growth and carcass traits selection. Difference results with other studies shows that this locus polymorphism might act differently among different chicken populations. Thus, the use of this locus as a genetic marker is not generally accepted yet. Further study is needed in other breeds and wider populations to strengthen this recommendation.

\section{Conclusions}

This present study obtained the polymorphism information of the T1857C GHSR locus and evidenced that this locus polymorphisms had significant association with carcass traits in F2 Kampung and broiler chicken cross. Accordingly, GHSR is a potential marker for growth and carcass traits in chicken with further study needed to confirm this issue.

\section{Acknowledgement}

This work was financially supported by the PMDSU Research Grant 2016 from Ministry of Research, Technology, and Higher Education, Republic of Indonesia.

\section{References}

Allendorf, FW, G Luikart, and SN Aitken. 2013. Conservation and the Genetics of Population $2^{\text {nd }}$ Ed. Wiley-Blackwell Publishing, UK. Bourdon, RM. 2000. Understanding Animal Breeding. Prentice Hall, NJ, US.

Campa, D, B Pardini, A Naccarati, L Vodickova, J Novotny, V Steinke, N Rahner, E Holinski-Feder, M Morak, HK Schackert, H Görgens, J Kötting, B Betz, M Kloor, C Engel, R Büttner, $\mathrm{P}$ Propping, A Försti, K Hemminki, $R$ Barale, $P$ Vodicka, and $F$ Canzian. 2010. Polymorphisms of genes coding for ghrelin and its receptor in relation to colorectal cancer risk: a two-step gene-wide case-control study. BMC Gastroenterology 10:112. doi: 10.1186/1471-230X-10-112.

Fang, M, Q Nie, C Luo, D Zhang, and X Zhang. 2010. Association of GHSR gene polymorphisms with chicken growth and carcass traits. Mol. Biol. Rep. 37:423-428.doi: 10.1007/s11033-009-9556-9.

Großauer, J, S Kosol, E Schrank, and K Zangger. 2010. The peptide hormone ghrelin binds to membrane-mimetics via its octanoyl chain and an adjacent phenylalanine. Bioorg. Med. Chem. 18:5483-5488. doi: 10.1016/j.bmc.2010.06.062.

Gueorguiev, M, C Lecoeur, D Meyre, M Benzinou, CA Mein, A Hinney, V Vatin, J Weill, B Heude, J Hebebrand, AB Grossman, M Korbonits, and $P$ Froguel. 2009. Association studies on ghrelin and ghrelin receptor gene polymorphisms with obesity.Obesity17:745-754.doi:10.1038/oby. 2008.589 . 
Honda, K, T Saneyasu, and H Kamisoyama. 2017. Gut hormones and regulation of food intake in birds. J.Poult.Sci.54:103-110.doi:10.2141/jpsa.0160100.

Jaelani, A, S Dharmawati, and Wanda. 2014. Berbagai lama penyimpanan daging ayam broiler segar dalam kemasan plastik pada lemari es (suhu $4^{\circ} \mathrm{C}$ ) dan pengaruhnya terhadap sifat fisik dan organoleptik. Ziraaáh 39(3):119-128.

Kaczor, U, K Poltowicz, M Kucharski, AM Sitarz, J Nowak, D Wojtysiak, and DA Zieba. 2017. Effect of ghrelin and leptin receptors genes polymorphisms on production results and physicochemical characteristics of $M$. pectoralis superficialis in broiler chickens. Anim. Prod. Sci. 57:42-50. DOI: 10.1071/AN15152.

Kaiya, H, K Kangawa, and M Miyazato. 2013. Ghrelin receptors in non-mammalian vertebrates. Front. Endocrinol.4(81).doi:10.3389/fendo.2013.00081.

Kaiya, H, K Kangawa, and M Miyazato. 2014. Molecular evolution of GPCRS ghrelin/ghrelin receptors. J. Mol. Endocrinol. 52(3): T87-T100. DOI: 10.1530/JME-13-0175.

Khaerunnisa, I, M Pramujo, II Arief, C Budiman, A Gunawan, Jakaria, and C Sumantri. 2016. Polymorphism of the T4842G myostatin gene is associated with carcass characteristics in Indonesian chickens. Intl. J. Poult. Sci. 15 (8): 316-324. DOI: 10.3923/ijps.2016.316.324.

Kitazawa, T, Y Maeda, and H Kaiya. 2009. Molecular cloning of growth hormone secretagoguereceptor and effect of quail ghrelin on gastrointestinal motility in Japanese quail. Regul. Pept.158:132-142.doi:10.1016/j.regpep.2009.07. 005.

Komatsu, M, Y Sato, T Negami, T Terada, O Sasaki, J Yasuda, A Arakawa, C Yoshida, H Takahashi, AEO Malau-Aduli, K Suzuki, and K Shimizu. 2015. Overdominance effect of the bovine ghrelin receptor (GHSR1a)-DelR242 locus on growth in Japanese Shorthorn Weaner Bulls: heterozygote advantage in bull selection and molecular mechanisms. Genes, Genomes, Genetics 5:271279. doi: 10.1534/g3.114.016105.

Lei, M, C Luo, X Peng, M Fang, Q Nie, D Zhang, G Yang, and $X$ Zhang. 2007. Polymorphism of growth-correlated genes associated with fatness and muscle fiber traits in chicken. Poult. Sci. 86:835-842.DOI:https://doi.org/10.1093/ps/86.5. 835.

Lengyel, AMJ. 2005. From growth hormone-releasing peptides to ghrelin: discovery of new modulators of $\mathrm{GH}$ secretion. Arq. Bras. Endocrinol. Metab. 50(1):17-24.DOI:10.1590/S0004-2730200600010 0004.

Mager, U, T Degenhardt, L Pulkkinen, M Kolehmainen, A Tolppanen, J Lindstro“m, JG Eriksson, C Carlberg, J Tuomilehto, and M
Uusitupa. 2008. Variations in the Ghrelin receptor gene associate with obesity and glucose metabolism in individuals with impaired glucose tolerance.PlosOne3(8):e2941.doi:10.1371/journa I.pone.0002941.

Nei, M and S Kumar. 2000. Molecular Evolution and Phylogenetics. New York: Oxford University Press.

Niarami, MD, AA Masoudi, and RV Torshizi. 2014. Association of single nucleotide polymorphism of GHSR and TGFB2 genes with growth and body composition traits in sire and dam lines of a broiler chicken. Anim. Biotechnol. 25(1):13-22. DOI: 10.1080/10495398.2013.803478

Nie, Q, M Fang, L Xie, X Peng, H Xu, C Luo, D Zhang, and $X$ Zhang. 2009. Molecular characterization of the ghrelin and ghrelin receptor genes and effects on fat deposition in chicken and duck. J. Biomed. Biotechnol. 2009:567120. doi:10.1155/2009/567120

Nie, Q, M Lei, J Ouyang, $H$ Zeng, G Yang, and $X$ Zhang. 2005. Identification and characterization of single nucleotide polymorphisms in 12 chicken growth-correlated genes by denaturing high performance liquid chromatography. Genet. Sel. Evol. 37:339-360. DOI: 10.1051/gse:2005005.

Padhi, MK. 2016. Importance of indigenous breeds of chicken for rural economy and their improvements for higher production performance.Scientifica2016.DOI:10.1155/2016/ 2604685.

Rak-Mardyla, A. 2013. Ghrelin role in hypothalamuspituitary-ovarian axis. J. Physiol. Pharmacol. 64(6):695-704.

Salakova, A, E Strakova, V Valkova, H Buchtova, and I Steinhauserova. 2009. Quality indicators of chicken broiler raw and cooked meat depending on their sex. Acta. Vet. Brno. 78: 497-504. doi:10.2754/avb200978030497.

Sambrook, J and D Russell. 2001. Molecular Cloning: A Laboratory Manual, 3rd ed. Cold Spring Harbor Laboratory Press, United States of America.

Sánchez-Bretaño, A, AM Blanco, S Unniappan, O Kah, MM Gueguen, Jl Bertucci, ÁL Alonso-Gómez, Al Valenciano, E Isorna, and MJ Delgado. 2015. In situ localization and rhythmic expression of ghrelin and GHS-R1 ghrelin receptor in the brain and gastrointestinal tract of goldfish (Carassius auratus). PLoS ONE 10(10): e0141043. doi:10.1371/journal.pone.0141043.

SAS Institute. 2008. SAS/STAT ${ }^{\circledR} 9.2$ User's Guide The GLM Procedure (Book Excerpt). SAS Institute Inc. Cary, NC, USA.

Sheng, Z, ME Pettersson, X Hu, C Luo, H Qu, D Shu, X Shen, Ö.Carlborg, and N Li. 2013. Genetic dissection of growth traits in a Chinese indigenous $\times$ commercial broiler chicken cross. 
Genomics 14:151. doi: 10.1186/1471-2164-14151

Swattitanun, W, and S Wattanachant. 2014. Effect of various temperature and storage time during process on physical quality and water-holding capacity of broiler breast meat. KKU Res. J. 19(5): 628-635.

Tanaka, M, T Miyazaki, I Yamamoto, N Nakai, Y Ohta, N Tsushima, M Wakita, and K Shimada. 2003. Molecular characterization of chicken growth hormone secretagogue receptor gene. Gen. Comp.Endocrinol.134:198-202. doi:10.1016/ S0016-6480(03)00247-8.

Wattanachant, S. 2008. Factors affecting the quality characteristics of Thai indigenous chicken meat. Suranaree J. Sci. Technol. 15(4).

Winarso, D. 2003. Perubahan karakteristik fisik akibat perbedaan umur, macam otot, waktu dan temperatur perebusan pada daging ayam kampung. J. Indon. Trop. Anim. Agric. 28(3):119132.

Yamamoto, I, Y Yoshimura, A Tsukada, N Kansaku, N Tsushima, and M Tanaka. 2008. Predominant expression of growth hormone secretagogue receptor in the caudal lobe of chicken pituitary and parallel developmental increase in expression of pituitary $\mathrm{GH}$ and proventriculus ghrelin mRNA. Anim. Sci. J. 79:116-121. doi: 10.1111/j.1740-0929.2007.00506.x

Yin, Y, Y Li, and W Zhang. 2014. The growth hormone secretagogue receptor: its intracellular signaling and regulation. Int. J. Mol. Sci. 15:4837-4855. doi:10.3390/ijms15034837.

Zendehdel, M and S Hassanpour. 2014. Central regulation of food intake in mammals and birds: a review. Neurotransmitter 1: e251. DOI: $10.14800 /$ nt. 251 